\title{
A Contemporary Assessment on Composite Titania onto Graphitic Carbon Nitride-Based Catalyst as Photocatalyst
}

\author{
Azami M. S. ${ }^{1}$, Jalil A. A ${ }^{2,3,}$, Hitam C. N. C. ${ }^{2,3}$, Mamat C. R ${ }^{1}$, Siang T. J. ${ }^{2}$, Hussain I. ${ }^{1}$, Hambali H. U. ${ }^{2}$ \\ ${ }^{1}$ Department of Chemistry, Faculty of Science, Universiti Teknologi Malaysia, 81310 UTM Johor Bahru, Johor, \\ Malaysia \\ ${ }^{2}$ School of Chemical and Energy Engineering, Faculty of Engineering, Universiti Teknologi Malaysia, 81310 \\ UTM Johor Bahru, Johor, Malaysia \\ ${ }^{3}$ Centre of Hydrogen Energy, Institute of Future Energy, Universiti Teknologi Malaysia, 81310 UTM Johor \\ Bahru, Johor, Malaysia \\ *Corresponding author: aishahaj@utm.my
}

\begin{abstract}
Article History
Received: July 22, 2018 Received in revised form: January 20, $2019 \quad$ Accepted: May 23, $2019 \quad$ Published Online: June 24, 2019
\end{abstract}

\begin{abstract}
Titanium dioxide $\left(\mathrm{TiO}_{2}\right)$ has drawn widespread interest by researchers as a precious semiconductor that is responsive towards photodegradation of various pollutants. This catalyst has its own limitations such as fast electron-hole recombination, wide band gap, and can only be utilised under ultraviolet (UV) region. In order to overcome these problems, the addition of a metalfree dopant is a common practice to prevent electron-hole recombination and enhance photodegradation under visible light. Among various types of metal-free catalysts, carbon nitride material has received much attention due to its numerous benefits such as good in terms of physical and chemical strength, as well as an attractive electronic band combined with a band gap (2.7 $\mathrm{eV})$. This review summarised recent works in the development of titania incorporated with graphitic carbon nitride $\left(\mathrm{g}-\mathrm{C}_{3} \mathrm{~N}_{4}\right)$ for enhanced photocatalytic activity.
\end{abstract}

Keywords: Photocatalyst; titanium dioxide; graphitic carbon nitride; heterojunction; visible light.

\subsection{INTRODUCTION}

Recently, the industrial development has caused a major threat towards aquatic life and the environment. This is due to industrial wastewater production such as from pesticides, heavy metals, dyes, pharmaceuticals, and personal care products, which are not simply biodegradable [1,2]. The utilisation of polluted water resources that are toxic and carcinogenic often leads to human health problem and aquatic life threat [2]. Therefore, many researchers have created various methods to solve this problem by using conventional treatment processes such as adsorption, chemical, and biological treatment. However, some contaminants in wastewater are intractable to degrade by applying these conventional processes. Nowadays, advanced oxidation process (AOP) is the most promising technique and has been explored by researchers to degrade various types of pollutants [3].

The photocatalytic reaction using a heterogeneous catalyst, which is one of the AOPs, has emerged as a destructive method that can mineralise most organic pollutants [4]. The use of semiconductor materials for that purpose has gained attention by many researchers for removal of organic pollutants from an aqueous solution. Various semiconductors such as $\mathrm{TiO}_{2}, \mathrm{ZnO}$, $\mathrm{Fe}_{2} \mathrm{O}_{3}, \mathrm{CdS}$, and $\mathrm{ZnS}$ can act as photocatalysts for light-induced redox process. Among them, titania $\left(\mathrm{TiO}_{2}\right)$ is the first semiconductor that was initially explored by Fujishima and Honda during photoelectrolysis of water to $\mathrm{H}_{2}$ in 1972 [3]. $\mathrm{TiO}_{2}$ has been studied extensively as a photocatalyst due to its inexpensive, chemically and photo-stable, non-toxic, and reusable. However, the fast electron-hole recombination and wide band gap of $\mathrm{TiO}_{2}(\sim 3.2 \mathrm{eV})$ limit its photoactivity and it is only applicable for ultraviolet (UV) irradiation [3-6]. Hence, many efforts have been devoted to extend the optical response of the 
photocatalyst by incorporation of $\mathrm{TiO}_{2}$ with $\mathrm{g}-\mathrm{C}_{3} \mathrm{~N}_{4}$. A short review on recent studies of $\mathrm{TiO}_{2} / \mathrm{g}-\mathrm{C}_{3} \mathrm{~N}_{4}$ composite is covered in this paper.

\subsection{TITANIUM DIOXIDE}

Titanium dioxide $\left(\mathrm{TiO}_{2}\right)$ is present in three phases, which are anatase, rutile, and brookite. Anatase and rutile are formed in a tetragonal structure whereas brookite appears in an orthorhombic structure as shown in Figure 1 [7]. These phases are similar based on the octahedral structure with different assembly patterns of each octahedral chain. Among them, anatase $\mathrm{TiO}_{2}$ is the most widely used in photocatalytic reaction and favoured for modification with other materials due to higher density of localised state that attributed towards slower charge carrier recombination $[8,9]$.

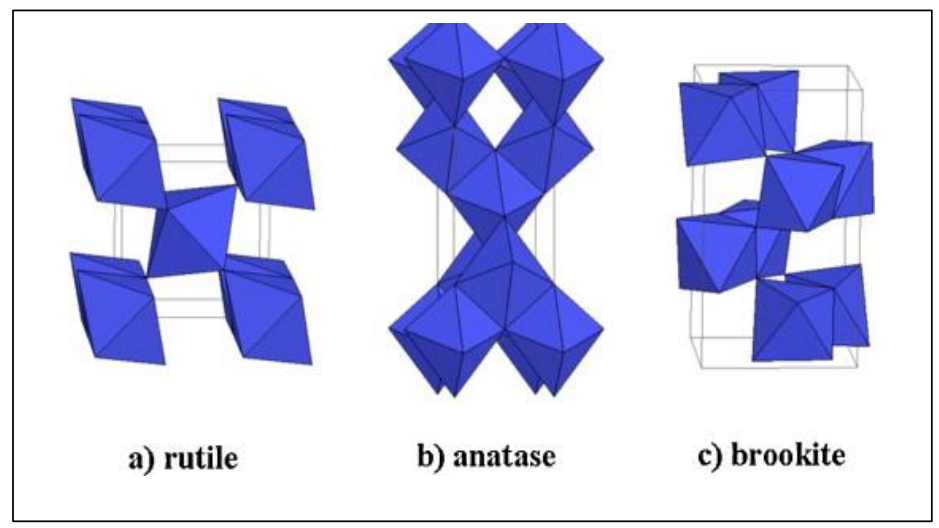

Figure 1. $\mathrm{TiO}_{2}$ crystal structures [7].

Photocatalysis reaction conducted in visible light irradiation has become the main focus nowadays since it requires low energy for catalyst activation [10]. Even though $\mathrm{TiO}_{2}$ is a promising photocatalyst, it is unable to absorb visible light due to its wide band gap energy, which limits its application range $[6,8,10]$. Hence, efforts have been devoted to prolong the optical response of $\mathrm{TiO}_{2}$ from UV to the visible light region and various strategies have been explored including doping with metals or nonmetals, dye or semiconductor sensitisation, and surface modification [11-13]. Nevertheless, it is a big challenge to obtain viable visible light active materials that are easily prepared, efficient, stable, and inexpensive.

\subsection{GRAPHITIC CARBON NITRIDE $\left(\mathrm{g}-\mathrm{C}_{3} \mathrm{~N}_{4}\right)$}

Polymeric $\mathrm{g}-\mathrm{C}_{3} \mathrm{~N}_{4}$ is depicted in Figure 2. Both triazine and heptazine have been discussed as possible tectonic units to constitute stable allotropes of $\mathrm{g}-\mathrm{C}_{3} \mathrm{~N}_{4}$. Based on density functional theory (DFT), the structure based on repeating heptazine units is more stable than the triazine units.

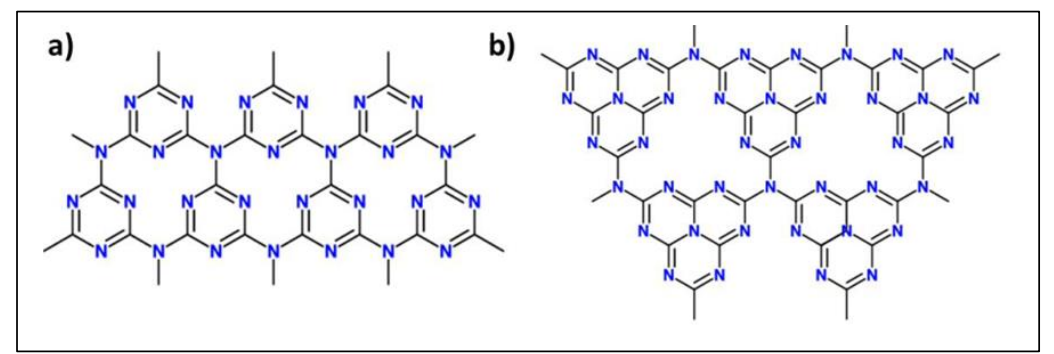

Figure 2. Representation of $\mathrm{g}-\mathrm{C}_{3} \mathrm{~N}_{4}$ based on a) triazine and b) heptazine units [14].

Particularly, $\mathrm{g}-\mathrm{C}_{3} \mathrm{~N}_{4}$ has become one of the most intensively researched photocatalytic materials due to its capability to be used in visible light radiance $[15,16]$. Besides, $\mathrm{g}-\mathrm{C}_{3} \mathrm{~N}_{4}$ has high thermal stability, biocompatible, and resistant to oxidation and hydrolysis processes. The constricted band gap of $\mathrm{g}-\mathrm{C}_{3} \mathrm{~N}_{4}(\sim 2.7 \mathrm{eV})$ enables it to penetrate visible light up to $460 \mathrm{~nm}$ [17]. 
However, g- $\mathrm{C}_{3} \mathrm{~N}_{4}$ still consists of high recombination probability of photogenerated electron-hole charge carriers that limits photocatalytic efficiency.

\section{0 $\mathrm{TiO}_{2} / \mathrm{g}-\mathrm{C}_{3} \mathrm{~N}_{4} \mathrm{COMPOSITE}$}

In improving photocatalytic activity, one of the strategies is to use a composite of two or more semiconductor photocatalysts that can absorb different parts of solar spectrum [18]. Composite semiconductors can also improve electron-hole separation due to the band off-sets and charge-transfer across interfaces. The coupling of carbon nitrides such as g- $\mathrm{C}_{3} \mathrm{~N}_{4}$ with other semiconductor materials has gained interest of many researchers, for example the production of g- $\mathrm{C}_{3} \mathrm{~N}_{4} / \mathrm{TiO}_{2}$ and or TiO$/ \mathrm{g}-$ $\mathrm{C}_{3} \mathrm{~N}_{4}$ composites [19-21]. These composites show great improvement in the efficiencies of photoactivity, thus promote its applications in energy production and environmental remediation. Recent studies on this photocatalyst are shown in Table 1. The composite catalysts showed high photodegradation performance towards various pollutants under visible light, which are attributed by the optimum band gap factor and better electron-hole pair separation.

Table 1. Recent study on $\mathrm{g}-\mathrm{C}_{3} \mathrm{~N}_{4} /$ titania photocatalyst.

\begin{tabular}{|c|c|c|c|c|c|}
\hline Photocatalyst & Synthesis Method & Pollutant & $\begin{array}{c}\text { Band } \\
\text { Gap (eV) }\end{array}$ & Performance & References \\
\hline $\begin{array}{l}\mathrm{TiO}_{2} / \mathrm{C}_{3} \mathrm{~N}_{4} \text { core- } \\
\text { shell nanowire } \\
\text { arrays }\end{array}$ & Hydrothermal & Bisphenol A & 2.90 & $95 \%$ & [21] \\
\hline $\begin{array}{l}\text { Core-shell structure } \\
\text { g- } \mathrm{C}_{3} \mathrm{~N}_{4} @ \mathrm{TiO}_{2}\end{array}$ & $\begin{array}{l}\text { Sol-gel approach } \\
\text { in-situ coating re- } \\
\text { assembled }\end{array}$ & Phenol & 1.70 & $30 \%$ & {$[22]$} \\
\hline $\begin{array}{l}\mathrm{TiO}_{2} / \mathrm{g}-\mathrm{C}_{3} \mathrm{~N}_{4} \text { hollow } \\
\text { nanotube }\end{array}$ & Molten salts & Rhodamine B & 2.48 & $95 \%$ & [23] \\
\hline $\begin{array}{l}\mathrm{TiO}_{2} / \mathrm{g}-\mathrm{C}_{3} \mathrm{~N}_{4} \\
\text { mesostructured } \\
\text { nanosheets }\end{array}$ & $\begin{array}{l}\text { Facile calcination- } \\
\text { sonication assisted } \\
\text { method }\end{array}$ & Phenol & 2.31 & $93 \%$ & [24] \\
\hline $\begin{array}{l}\text { Core-shell } \mathrm{TiO}_{2} @ \mathrm{~g}- \\
\mathrm{C}_{3} \mathrm{~N}_{4} \text { hollow } \\
\text { microspheres }\end{array}$ & $\begin{array}{l}\text { Two-step self- } \\
\text { assembly procedure } \\
\text { with the assistance } \\
\text { of ultrasonic } \\
\text { dispersion }\end{array}$ & Rhodamine B & 2.75 & $93 \%$ & [25] \\
\hline $\begin{array}{l}\text { Porous g- } \mathrm{C}_{3} \mathrm{~N}_{4} / \mathrm{TiO}_{2} \\
\text { heterostructure }\end{array}$ & $\begin{array}{l}\text { In-situ assembling } \\
\text { of small needle-like } \\
\mathrm{TiO} 2 \text { on the surface } \\
\text { of ultrathin g-C3N4 } \\
\text { sheets }\end{array}$ & Acid Orange & 2.90 & $82 \%$ & [26] \\
\hline $\begin{array}{l}\text { Mesoporous } \mathrm{TiO}_{2} / \mathrm{g}- \\
\mathrm{C}_{3} \mathrm{~N}_{4} \text { microspheres }\end{array}$ & Facile nanocoating & Phenol & 1.50 & $25 \%$ & [27] \\
\hline $\begin{array}{l}\text { Brookite/anatase } \\
\mathrm{TiO}_{2} / \mathrm{g}-\mathrm{C}_{3} \mathrm{~N}_{4} \\
\text { heterojunction }\end{array}$ & Facile nanocoating & Phenol & 1.80 & $20 \%$ & [28] \\
\hline $\begin{array}{l}\text { Carbon } \\
\text { nitride/titania } \\
\text { nanotubes }\end{array}$ & $\begin{array}{l}\text { High-temperature } \\
\text { calculation method }\end{array}$ & $\begin{array}{c}2- \\
\text { chlorophenol }\end{array}$ & 2.60 & $90 \%$ & [29] \\
\hline
\end{tabular}

\subsection{MECHANISM OF $\mathrm{TiO}_{2} / \mathrm{g}_{-} \mathrm{C}_{3} \mathrm{~N}_{4} \mathrm{COMPOSITE}$}

Most of the $\mathrm{TiO}_{2} / \mathrm{g}-\mathrm{C}_{3} \mathrm{~N}_{4}$ composites show a similar proposed mechanism. When $\mathrm{TiO}_{2} / \mathrm{g}-\mathrm{C}_{3} \mathrm{~N}_{4}$ is exposed to visible light, the photon could be absorbed directly by $\mathrm{g}-\mathrm{C}_{3} \mathrm{~N}_{4}$ to generate the electron-hole pairs in valence band (VB) and conduction band (CB), respectively [30]. The electron from $\mathrm{g}-\mathrm{C}_{3} \mathrm{~N}_{4}$ can easily migrate from its $\mathrm{CB}$ to the $\mathrm{CB}$ of $\mathrm{TiO}_{2}$ since $\mathrm{g}-\mathrm{C}_{3} \mathrm{~N}_{4}$ has more negative $\mathrm{CB}$ level $(-1.12 \mathrm{eV})$ than $\mathrm{TiO}_{2}(-0.29 \mathrm{eV})$ [31]. Meanwhile, the holes from $\mathrm{TiO}_{2}$ surface will migrate to the VB of $\mathrm{g}-$ $\mathrm{C}_{3} \mathrm{~N}_{4}$. The electron on $\mathrm{CB}$ of $\mathrm{TiO}_{2}$ can abduct $\mathrm{O}_{2}$ to generate superoxide anion radical $\left(\cdot \mathrm{O}^{2-}\right)$, which is one of the active species that can oxidise the pollutant. Meanwhile, the holes on $\mathrm{g}-\mathrm{C}_{3} \mathrm{~N}_{4}$ also play an important role in photodegradation process by forming hydroxyl radical $(\cdot \mathrm{OH})$ when reacted with water. The pollutant will be decomposed to form $\mathrm{CO}_{2}$ and $\mathrm{H}_{2} \mathrm{O}$ via photocatalysis with the reactive $\cdot \mathrm{O}^{2-}$ and $\bullet \mathrm{OH}$ as illustrated in Figure 3. 


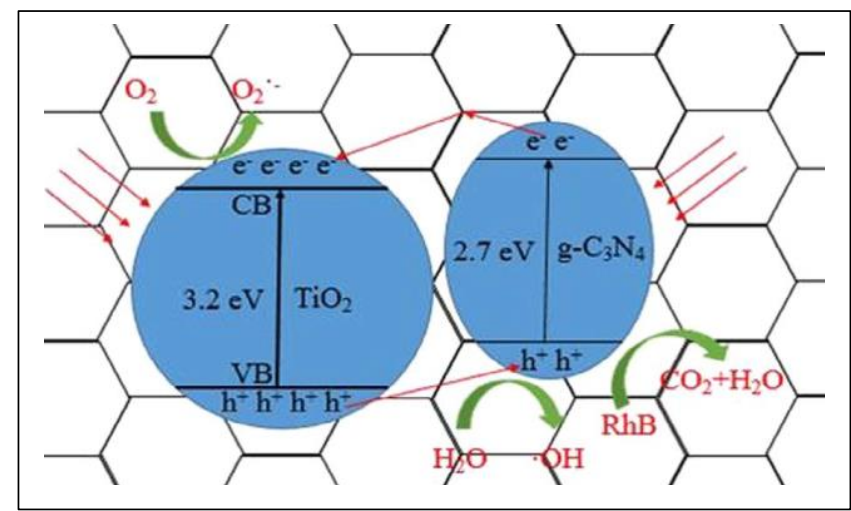

Figure 3. Mechanism for photo-degradation of $\mathrm{TiO}_{2} / \mathrm{g}-\mathrm{C}_{3} \mathrm{~N}_{4}$ composite [30].

\subsection{CONCLUSION}

From this review, it can be concluded that the coupling of these two semiconductors will increase the efficiency of electron transfer separation process. Consequently, the electron life is significantly prolonged and recombination process can be reduced, thus resulting in remarkable photocatalytic degradation of pollutants.

\section{Acknowledgements}

This research work was sponsored and supported by Universiti Teknologi Malaysia through Research University Grant No. $19 \mathrm{H} 04$.

\section{References}

[1] Mohamed, N. B., and S. A. Raed. 2015. Review Article: Chemical Oxidation and Membrane Filtration Technologies for Wastewater Treatment. Australian Journal of Basic and Applied Sciences. 9: 263-273.

[2] Azami, M. S., W. I. Nawawi, Ali H. Jawad, M. A. M Ishak, K. Ismail. 2017. N-doped $\mathrm{TiO}_{2}$ Synthesised via Microwave Induced Photocatalytic on RR4 Dye Removal under LED Light Irradiation. Sains Malaysiana 46: 1309-1316.

[3] Fujishima, A., and K. Honda. 1972. Electrochemical Photolysis of Water at a Semiconductor Electrode. Nature. 238: 37-38.

[4] Nawawi, W. I., M. S. Azami, L. S. Ang, M. A. M. Ishak, K. Ismail. 2017. Modification and Characterization of Microwave Assisted N doped TiO $2-$ A Photodegradation Study under Suspension and Immobilized System. Water Quality Research Journal of Canada. 51-63.

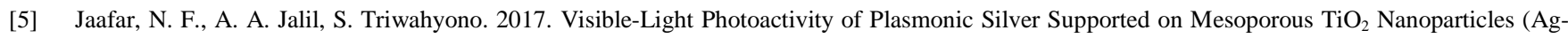
MTN) for Enhanced Degradation of 2-chlorophenol: Limitation of Ag-Ti Interaction. Applied Surface Science. 392: 1068-1077.

[6] Hitam, C. N. C., A.A. Jalil, S. Triwahyono, A.F.A. Rahman, N.S. Hassan, N.F. Khusnun, S.F. Jamian, C.R. Mamat, W. Nabgan, A. Ahmad. 2018 Effect of Carbon-Interaction on Structure-Photoactivity of $\mathrm{Cu}$ Doped Amorphous $\mathrm{TiO}_{2}$ Catalysts for Visible-Light-Oriented Oxidative Desulphurization of Dibenzothiophene. Fuel. 216: 407-417.

[7] Regonini, D., C. R. Bowen, A. Jaroenworaluck, R. Stevens. 2013. A Review of Growth Mechanism, Structure and Crystallinity of Anodized TiO ${ }_{2}$ Nanotubes. Materials Science and Engineering: R: Reports. 74: 377-406.

[8] Aziz, F. F. A., A. A. Jalil, S. Triwahyono, M. Mohamed. 2018. Controllable Structure of Fibrous $\mathrm{SiO}_{2}-\mathrm{ZSM}-5$ Support Decorated with TiO ${ }_{2}$ Catalysts for Enhanced Photodegradation of Paracetamol. Applied Surface Science. 455: 84-95.

[9] Valentin, C. D., and G. Pacchioni. 2013. Trends in Non-Metal Doping of Anatase $\mathrm{TiO}_{2}$ : B, C, N and F. Catalysis Today. 206:12-18.

[10] Azami, M. S., S. K. Ain, R. Zaharudin, F. Bakar, W. I. Nawawi. 2016. Nitrogen Doped $\mathrm{TiO}_{2}$ Prepared under Microwave Irradiation: Effect of Different Irradiation Light. Applied Mechanics and Materials. 835: 372-377.

[11] Pan, L., G. Shen, J. Zhang, X. Wei, L. Wang, J. Zou, X. Zhang. 2015. TiO - ZnO Composite Sphere Decorated with ZnO Clusters for Effective Charge Isolation in Photocatalysis. Industrial \& Engineering Chemistry Research. 54: 7226-7232. 
[12] Azami, M. S., W. I. Nawawi, D. S. M. Shukri. 2017. Formation of Predominant Interstitial N-TiO2 using Physical Preparation under Microwave Irradiation for Reactive Red 4 Dye Removal. Desalination and Water Treatment. 92: 172-180.

[13] Jaafar, N. F., A. A. Jalil, S. Triwahyono, J. Efendi, R. R. Mukti, R. Jusoh, N. W. C. Jusoh, A. H. Karim, N. F. M. Salleh, V. Suendo. 2015. Direct in Situ Activation of Ag0 Nanoparticles in Synthesis of $\mathrm{Ag} / \mathrm{TiO}_{2}$ and its Photoactivity. Applied Surface Science. 338: 75-84.

[14] Li, J., Y. Liu, H. Li, C. Chen J. 2016. Fabrication of $\mathrm{g}_{-} \mathrm{C}_{3} \mathrm{~N}_{4} / \mathrm{TiO}_{2}$ Composite Photocatalyst with Extended Absorption Wavelength Range and Enhanced Photocatalytic Performance. Journal of Photochemistry and Photobiology A: Chemistry. 317: 151-160.

[15] Yasuhiro, S. K., Yusuke, S. Hirokatsu, T. Shunsuke, I. Satoshi, H. Takayuki. 2015. Effects of Surface Defects on Photocatalytic $\mathrm{H}_{2} \mathrm{O}_{2}$ Production by Mesoporous Graphitic Carbon Nitride under Visible Light Irradiation. ACS Catalysis. 5: 3058-3066.

[16] Mohammad, R. G., B. Francois, D. Trong-On. 2016. Graphitic Carbon Nitride-Titanium Dioxide Nanocomposite for Photocatalytic Hydrogen Production under Visible Light. International Journal of Chemical Reactor Engineering. 14: 851-858.

[17] Usanginee, N., M. Lagnamayee, P. Kulamani. 2015. Visible Light Driven Novel g-C $\mathrm{N}_{4} / \mathrm{NiFe}_{\mathrm{LDH}}$ Composite Photocatalyst with Enhanced Photocatalytic Activity towards Water Oxidation and Reduction Reaction. Journal of Materials Chemistry A. 3: 18622-18635.

[18] Yanlong, T., C. Fuxing, Z. Xiang, Y. Fei, Z. Baocheng, C. Zhi, L. Jiyang, X. Fengna, D. Xiaoping. 2014. Solvothermal Synthesis and Enhanced Visible Light Photocatalytic Activity of Novel Graphitic Carbon Nitride--Bi ${ }_{2} \mathrm{MoO}_{6}$ Heterojunctions. Powder Technology. 267: $126-133$.

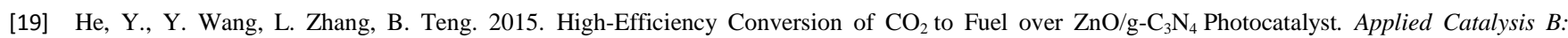
Environmental. 168-169:1-8.

[20] He, Y., L. Zhang, M. Fan, X. Wang, L. W. Mikel, Q. Nong, Y. Wu, L. Z. Zhao. 2015. Z-scheme SnO ${ }_{2-x} /$ g-C $_{3} \mathrm{~N}_{4}$ Composite as an Efficient Photocatalyst for Dye Degradation and Photocatalytic $\mathrm{CO}_{2}$ Reduction. Solar Energy Materials and Solar Cells. 137: 175-184.

[21] Wang, Y., Q. Wu, Y. Li, L. Liu, Z. Geng, Y. Li, J. Chen, W. Bai. 2018. Controlled Fabrication of TiO $\mathrm{C}_{2} / \mathrm{C}_{3} \mathrm{~N}_{4}$ core-shell Nanowire Arrays: a VisibleLight-Responsive and Environmental Friendly Electrode for Photoelectrocatalytic Degradation of Bisphenol A. Journal of Materials Science: Materials in Electronics. 53: 11015-11026.

[22] Wang, Y., W. Yang, X. Chen, J. Wang, Y. Zhu. 2018. Photocatalytic Activity Enhancement of Core-Shell Structure g-C $\mathrm{N}_{4} @ \mathrm{TiO}_{2}$ via Controlled Ultrathin $\mathrm{g}_{-} \mathrm{C}_{3} \mathrm{~N}_{4}$ Layer. Applied Catalysis B: Environmental 220: 337-347.

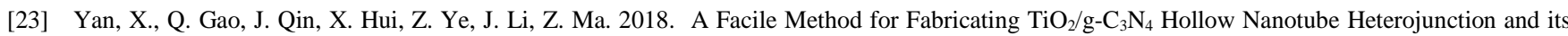
Visible Light Photocatalytic Performance. Materials Letters. 217: 1-4.

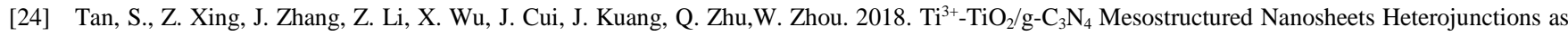
Efficient Visible-Light-Driven Photocatalysts. Journal of Catalysis. 357: 90-99.

[25] Ma, L., G. Wang, C. Jiang, H. Bao, Q. Xua. Synthesis of Core-Shell TiO $@ \mathrm{~g}_{2} \mathrm{C}_{3} \mathrm{~N}_{4}$ Hollow Microspheres for Efficient Photocatalytic Degradation of Rhodamine B under Visible Light. Applied Surface Science. 430: 263-272.

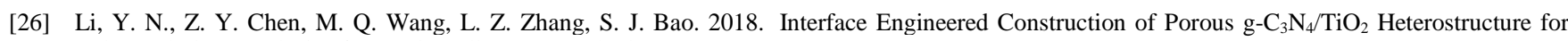
Enhanced Photocatalysis of Organic Pollutants. Applied Surface Science. 440: 229-236.

[27] Wei, H., W. A. McMaster, J. Z. Y. Tan, L. Cao, D. Chen, R. A. Caruso. 2017. Mesoporous TiO ${ }_{2} / g-C_{3} \mathrm{~N}_{4} \mathrm{Microspheres}$ with Enhanced Visible-Light Photocatalytic Activity. Journal of Physical Chemistry C. 121: 22114-22122.

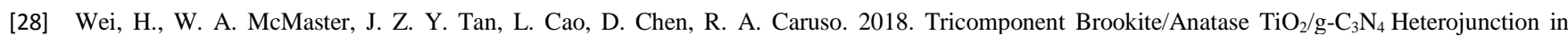
Mesoporous Hollow Microspheres for Enhanced Visible-Light Photocatalysis. Journal of Materials Chemistry A. 6: $7236-724$.

[29] Anjum, M., R. Kumar, S. M. Abdelbasir, M. A. Barakat. 2018. Carbon Nitride/Titania Nanotubes Composite for Photocatalytic Degradation of Organics in Water and Sludge: Pre-Treatment of Sludge, Anaerobic Digestion and Biogas Production. Journal of Environmental Management. 223 : $495-502$.

[30] Zhang, J. J., S. S. Fang, J. Y. Mei, G. P. Zheng, X. C. Zheng, X. X. Guan. 2018. High-Efficiency Removal of Rhodamine B Dye in Water using g-C N $_{4}$ and $\mathrm{TiO}_{2}$ co-Hybridized 3D Graphene Aerogel Composites. Separation and Purification Technology. 194: 96-103.

[31] Boonprakob, N., N. Wetchakun, S. Phanichphant, D. Waxler, P. Sherrell, A. Nattestad, J. Chen, B. Inceesungvorn. 2014. Enhanced visible-light photocatalytic activity of $\mathrm{g}-\mathrm{C}_{3} \mathrm{~N}_{4} / \mathrm{TiO}_{2}$ films. Journal of Colloid and Interface Science. 417: 402-409. 